\title{
MINERAL RESOURCE POTENTIAL OF THE WILD ROGUE WLDERNESS (NF105), COOS AND CURRY COUNTIES, OREGON
}

\section{SUMMARY REPORT}

By

\author{
Floyd Gray, Jocelyn A. Peterson, Richard J. Blakely, and Lisa Senior \\ U.S. Geological Survey
}

and

Michael S. Miller, and Richard S. Gaps

U.S. Bureau of Mines

\section{STUDIES RELATED TO WILDERNESS}

Under the provisions of the Wilderness Act (Public Law 88-577, September 3, 1964) and the Joint Conference Report on Senate Bill 4, 88th Congress, the U.S. Geological Survey and the U.S. Bureau of Mines have been conducting mineral surveys of wilderness and primitive areas. Areas of ficially designated as "wilderness," "wild," or "canoe" when the act was passed were incorporated into the National Wilderness Preservation System, and some of them are presently being studied. The act provided that areas under consideration for wilderness designation should be studied for suitability for incorporation into the Wilderness System. The mineral surveys constitute one aspect of the suitability studies. The act directs that the results of such surveys are to be made available to the public and be submitted to the President and the Congress. This report discusses the results of a mineral survey of the Wild Rogue Wilderness (NF105), Siskiyou National Forest and adjacent U.S. Bureau of Land Management public domain, Coos and Curry Counties, Oregun. The area was established as a wilderness by Public Law 95-237, February 28, 1978.

\section{SUMMARY}

Geologic, geophysical, and geochemical investigations and a survey of mines, prospects, and quarries have been conducted to evaluate the mineral resource potential of the Wild Rogue Wilderness, Coos and Curry Counties, southwestern Oregon (fig. 1). The wilderness lies within the western edge of the Klamath Mountains province of Oregon, just beyond the western border of the western Jurassic belt as defined by Irwin (1966). The area is underlain largely by faulted pre-Tertiary volcanic and plutonic rocks that, on the west side, are either overlain by Tertiary sedimentary rocks of the Coast Ranges or are in thrust contact with the Jurassic and Cretaceous Riddle Formation. To the east the pre-Tertiary volcanic and plutonic complex is faulted against the Dothan Formation of Jurassic and Cretaceous age. Approximately 800 mining claims, a third of which are for placer gold, have been recorded historically in or adjacent to the Wild Rogue Wilderness.

Areas with different degrees of mineral resource potential were designated on the basis of the presence of some combination of the following criteria: (1) known mineral occurrences, (2) favorable host rocks, (3) drainage basins with groups of geochemically anomalous stream-sediment and rock samples, and (4) aeromagnetic anomalies. The geologic environment of the Wild Rogue Wilderness suggests the possible existence of deposits of the following commodities: gold, silver, copper, lead, zinc, and coal. The wilderness is estimated to contain $11,477.9 \mathrm{oz}$ of gold and $1,960 \mathrm{oz}$ of silver and the potential for copper is high. The mineral resource potential for zinc, lead, and coal is not considered to be economically significant.

\section{INTRODUCTION}

The Wild Rogue Wilderness is located in Coos and Curry Counties, southwestern Oregon and is covered by parts of the Bone Mountain, Marial, and Agness 15-minute quadrangles. The area is approximately $19 \mathrm{mi}$ long and as much as $5 \mathrm{mi}$ wide and covers approximately 35,818 acres, extending from near the town of Agness in the southwest, to Mount Bolivar in the northeast (fig. 1). The Bureau of Land Management has transfered at least some of its authority in the wilderness to the Forest Service. The wilderness area can be accessed in the southwest via U.S. Forest Service road networks from the town of Agness and Powers, Oregon, which are about $20 \mathrm{mi}$ to the northwest. To reach the area in the northeast, Forest Service roads stemming from Grants Pass can be used. The area, although having nearly continuous rock exposure in the steeply etched canyon of the Rogue River, is densely populated by manzanita, golden chinkapin, tan oak, and madrone as well as Douglas fir, sugar pine, Port Orford cedar, and others. The area is characterized by several diverse geologic terranes described in detail by Gray and others (1982).

Previous geologic studies in nearby areas were done by Wells and Walker (1953) and Baldwin (1969). Later studies that include the geology within parts of the wilderness are by Wells (1955), Wells and Peck (1961), Baldwin and Rudd (1972), Kent (1972), Purdom (1977), and Ramp and others (1977).

Geologic mapping, geochemical sampling, and prospect examination for this study were done in 1979 and 1980. An aeromagnetic survey of the area was flown and compiled in 1978 as part of a larger survey of the Medford $1^{\circ}$ by $2^{\circ}$ sheet (U.S. Geological Survey, 1979). Detailed discussions on the geology, geochemistry, geophysies and mining history are given in Gray and others (1982), Ramp and Gray (1980), Gray and McKee (1981), Gray and Peterson (1982) Peterson and Gray (1983), Blakely and Senior (1983), and Miller and Gaps (1982)

Mining activity in the Wild Rogue Wilderness began about 1853 with the discovery of placer gold deposits on the Rogue River. The source of the placer deposits was subsequently traced to several lode deposits upstream, the largest being in the Mule Creek area (Purdom, 1977). Mining activity on the Rogue River and its tributaries has continued, although at a declining rate, to the present day. 


\section{GEOLOGY, GEOCHEMISTRY, AND GEOPHYSICS PERTAINING TO MINERAL RESOURCE ASSESSMENT}

The Wild Rogue Wilderness is located along the western edge of the Klamath Mountains province of Oregon. The wilderness is underlain largely by faulted pre-Tertiary volcanic and plutonic rocks that are unconformably overlain by Tertiary sedimentary rocks and the Jurassic and Cretaceous Riddle Formation on the west and are fault bounded by the Dothan Formation of Jurassic and Cretaceous age on the east (fig. 2).

Pre-Tertiary igneous rocks underlie about $26 \mathrm{mi}^{2}$ of the Wild Rogue Wilderness. The igneous rocks of the wilderness area were collectively called the Rogue Formation by Baldwin (1969), a term originally applied by Wells and Walker (1953) to a sequence of metavolcanic rocks that lie east of the Dothan Formation and some $12 \mathrm{mi}$ east of the wilderness. With the exception of small slivers of serpentinite dragged along fault planes, Jurassic gabbro is the oldest rock in the wilderness. The gabbro includes both foliated and massive varieties and is everywhere metamorphose to a low-grade greenschist facies. Foliated, locally gneissic gabbro occurs as screens within a sheeted sequence of diabasic dikes. Massive gabbro, on the other hand, structurally underlies andesitic to dacitic volcanic rocks along a northeast-trending contact from Mule Mountain to Mount Bolivar. The massive gabbro hosts irregular andesitic to dacitic dike swarms that are best exposed on the ridges southwest of Mount Bolivar. The separate associations of foliated gabbro within sheeted diabasic dikes and of the massive gabbro with silicic volcanic rocks indicate different transitional crustal stratigraphic levels that have been juxtaposed by faulting. The zone separating these two structural and stratigraphic regimes is locally intruded by altered dioritic to granitic rocks and marked by mylonitized rocks, phyllite, and quartz veins, and it may represent an area of crustal suturing. A similar metamorphic character of lower greenschist facies assemblages pervades most of the rocks exposed in the massive gabbro horizon of the igneous terrane.

The sheeted dike sequence, best exposed along the Rogue River at Inspiration Point (Ramp and Gray, 1980), consists largely of dikes, but screens of gabbroic country rock constitute as much as 50 percent of some exposures. Detached lenticular fragments, $0.5-1.5 \mathrm{ft}$ by $3-6 \mathrm{ft}$ in size, of foliated gabbro in the dikes display a consistent foliation orientation and are interpreted as fractured, unrotated pieces of country rock. Locally, large proportions of gabbro fragments in dikes (for example, near Stair Creek) may indicate proximity to the main gabbroic body, which is not exposed.

The diabase dikes appear to be spatially associated with a small fault slice of sedimentary and amygdaloidal basaltic rocks that are exposed near Devils Backbone and the mouth of East Creek. The basalt unit consists of greenschistfacies basalt flows with lenses of shale and minor amounts of chert. The sequence of sheeted dikes, basalt (greenstone), and minor amounts of chert and shale, are characteristic of the upper part of an ophiolite suite formed at a spreading oceanic ridge (Coleman, 1977). Subsequent faulting and intrusive activity have truncated the base of the ophiolite suite. Both the basalt and the sheeted dikes are intruded by diorite which has yielded a potassium-argon age of $155 \mathrm{~m} . \mathrm{y}$., similar to ages of a number of widespread intrusive bodies in the Klamath Mountains (Hotz, 1971; Gray and McKee, 1981).

With no observed diorite intrusives cutting andesitic to dacitic rocks exposed northwest of the massive gabbro unit, these volcanic rocks represent a different exhalative sequence than those rocks included in the Rogue Formation. Preliminary potassium-argon ages of 133 and $122 \mathrm{~m} . \mathrm{y}$. were obtained from an andesite and a dacite, respectively (Gray and McKee, 1981). Therefore, these volcanic rocks are believed to be Early Cretaceous, and possibly Jurassic, in age and are not part of the Rogue Formation as originally defined by Wells and Walker (1953) for a predominantly fragmental metavolcanic sequence exposed $25 \mathrm{mi}$ east of the wilderness. These younger volcanic rocks found within the wilderness consist of vesicular andesite flows, minor shallow andesitic-intrusive rocks, agglomerate, tuff, hornblende dacite, quartz dacite, and rhyolitic rocks, and they probably represent an island-arc environment. This sequence may be as much as $9,000 \mathrm{ft}$ thick between the Dothan Formation, to the southeast, and the Riddle Formation to the west, where it forms a thrust sheet overriding the Riddle Formation. The leading edge of the thrust,composed of island-arc volcanic rocks, gabbroic massifs, and sheeted dikes, overlies Jurassic sedimentary rocks and forms the western boundary of the pre-Tertiary igneous complex of the Wild Rogue Wilderness.

During or after the latest stages of magmatism, the Dothan and Riddle Formations were deposited contemporaneously in separate sedimentary basins. Petrologic characteristics indicate that the two units were derived from different sources. Thrust faulting juxtaposed rocks of the two basins, then tightly folded and locally overturned them; a less pervasive compressional tectonic regime followed and produced broad folds and vertical faults.

Three marine transgressive cycles during the Eocene are represented by the Lookingglass and Flournoy Formations of Baldwin (1974) and the Tyee Formation. Angular unconformities that bound all three formations indicate the tectonic activity continued throughout the Eocene. After the Tyee Formation was deposited, the region was uplifted and eroded. Dissection of the highlands by the ancestral Rogue River began by late Tertiary or early Pleistocene time, leaving terraces along the canyon walls.

Mass wasting in the form of massive rock flows has occurred in recent geologic time. These flows apparently originated from the failure of cliffs composed of the Tyee Formation in the vicinity of Panther Ridge and Hanging Rock. Debris from these rock falls mixed with tangled vegetation, soil, and water during periods of rapid runoff and was channeled along steep-gradient creeks such as Blossom Bar, Paradise, and Clay Hill Creeks. The rock flow along Blossom Bar Creek probably occurred within the past 100 years. It deposited large quantities of debris, including blocks $150 \mathrm{ft}$ in diameter, that form the treacherous Blossom Bar rapids in the Rogue River.

\section{GEOCHEMISTRY}

A geochemical survey of the Wild Rogue Wilderness was undertaken by the U.S. Geological Survey in 1979 and 1980. Forty stream-sediment samples and 256 whole-rock samples were collected from the wilderness and adjacent areas. Descriptions of sampling methods, analytical techniques, sample locations, and analytical data are presented by Gray and Peterson (1982). Geochemical anomaly maps, anomaly interpretations, and data-reduction procedures are discussed by Peterson and Gray (1983).

Data for the Wild Rogue Wilderness indicate that a number of the geochemically anomalous areas are associated with intermediate to silicic island-arc volcanic rocks, quartz veins in gabbro and diorite, or Tertiary sedimentary materials deposited along the Rogue River. Several elements, including lead, molybdenum, copper, silver, zinc, and gold, occur in anomalously high concentrations as shown on histograms and cumulative frequency charts (Peterson and Gray, 1983).

Both rock and stream-sediment data reveal anomalous amounts of copper, lead, silver, and zine in a number of localities associated with shears, gossan, and altered rocks in the island-arc volcanic materials. Anomalous concentrations near the Old Red, Underslide, and Tina H-Dinawadja mines (fig. 3, Nos. 24, 16, and 34) are associated with vein and gossan material that carry gold, lead, zinc, silver and copper. Anomalous amounts of silver, lead, copper, molybdenum, and nickel occur in the Mount Bolivar area, associated with altered leached rocks as well as vein and gossan zones. In each area where anomalous values were obtained from stream-sediment samples, correlative bedrocksample anomalies were also detected.

Geochemically anomalous amounts of silver, copper, and molybdenum occur south of Half Moon Bar in younger andesitic and dacitic dikes, thought to be feeders for, or intrusive masses contemporaneous with, island-arc volcanism. These small scattered dikes occur throughout the older ophiolite terrane. Dike clusters along or near the 
Rogue River may be the source of anomalies in the streamsediment samples of this region.

Geochemically anomalous values are associated with veins in gabbroic and dioritic intrusive rocks in the Mule Mountain ridge area north of Marial; anomalous gold, silver, zinc, and copper are present in in rock samples, and anomalous copper and zine values occur in stream-sediment samples. The mineralization here is associated with quartz veins and shears. The concentrations of most elements in samples from the mafic intrusive terrane, however, fall within the range of normal crustal abundances for mafic rocks (Turekian and Wedepohl, 1961).

Stream-sediment samples derived from Tertiary sedimentary rocks downstream from Clay Hill Creek are anomalous in copper, silver, zinc, molybdenum, and lead and are geochemically similar to those obtained from the younger-volcanic terrane. These anomalies may represent enrichment from source terranes other than those presently found in the wilderness, or perhaps they represent seepage from an underlying source rock similar to the younger volcanic terrane. It is also possible that human activity along this part of the Rogue River and its tributaries has caused contamination of the streams. Geochemical data for the Tertiary bedrock materials (graywacke, shale, and minor conglomerate and argillite) in this area do not show corresponding anomalous values of the same elements. The rock analyses match average chemical abundances except for cobalt, chromium, and nickel. High values of these elements are from widely scattered samples and probably represent detrital material eroded from mafic source rocks to the north and east. Chemical, isotopic, and mineralogic data from the graywacke of the Flournoy Formation indicate a mafic source (Peterman and others, 1981).

\section{GEOPHYSICS}

A total-field aeromagnetic survey was flown and compiled in 1978 by a private contractor as part of a larger survey of the Medford $1^{\circ}$ by $2^{\circ}$ (scale $1: 250,000$ ) quadrangle (U.S. Geological Survey, 1979). Flight lines were flown at a constant barometric elevation of $4,500 \mathrm{ft}$ above sea level, directed east-west, and spaced $1 \mathrm{mi}$ apart. One north-south line was flown over the map area to aid in data compilation. Data were interpolated to a rectangular grid with $0.3-\mathrm{mi}$ spacing and machine contoured at 20-gamma intervals (Blakely and Senior, 1983).

Several of the magnetic anomalies indicated by the survey correspond to known geologic features and are consistent with magnetic properties and patterns of geologic structures and rock types exposed at the surface. One anomaly, for example, consists of a linear north-south gradient that separates the subdued magnetic values of the Dothan Formation to the east from high-amplitude, shortwavelength anomalies to the west. This anomaly coincides with the trend of the steeply dipping fault near the eastern boundary of the wilderness that separates graywacke and shale from the tectonic wedge of volcanic and intrusive rocks to the west.

Most of the magnetic anomalies, however, appear to be due to source rocks beneath those exposed at the surface. The postulated source of the major anomalies of the Wild Rogue Wilderness is a relatively thin shallow sheet, possibly composed of ultramafic or gabbroic material, that terminates abruptly near the eastern edge of the volcanic wedge. The top of the source is less than $1,300 \mathrm{ft}$ below the surface and may be relatively thin (less than $1.2 \mathrm{mi}$ thick). The extension of these anomalies to the west suggests that the thrust fault along the western boundary of the volcanic wedge and the numerous normal faults within the wedge are strictly nearsurface structures. Magnetic modeling (Blakely and Senior, 1983) shows that any deposit associated with surface rocks may have a maximum depth of approximately $1,300 \mathrm{ft}$; it also implies, however, that rocks of the volcanic-intrusive wedge (and associated mineral deposits) may extend farther west beneath the thrust fault exposed at the surface.

A fairly steep-sided circular anomaly over dacite around Saddle Peaks appears to be the only substantial anomaly within the wilderness that is caused by rocks that crop out at the surface. Although the dacite produces a substantial anomaly in this area, it appears to be only weakly magnetic elsewhere. Mount Bolivar, for example, is a larger topographic feature than the Saddle Peaks and is composed of the same dacitic unit, but produces only a subdued magnetic anomaly. The northern edge of the Saddle Peaks anomaly is over a mineralized zone identified by a geochemically anomalous area (Peterson and Gray, 1983) and the magnetic anomaly may reflect a southward extension by perhaps $0.6 \mathrm{mi}$ of the mineralized zone. The area may also be a remnant volcanic center since it is associated with a large volume of agglomerate, fragmental tuffs, and fine-grained air-fall tuffs.

We conclude from the magnetic data that only the Saddle Peaks region of the Wild Rogue Wilderness has surface rocks that are sufficiently magnetic to produce an aeromagnetic anomaly (Blakely and Senior, 1983). Elsewhere (for example, Mount Bolivar), the dacite is much less magnetic, so it is possible that the Saddle Peaks anomaly reflects an extension of a mineralized zone. Except for this one region, the major anomalies in the wilderness are not caused by the volcanic and intrusive rocks exposed at the surface; modeling experiments indicate that the source may be less than $1,300 \mathrm{ft}$ below the topographic surface.

\section{MINING DISTRICTS AND MINERALIZATION}

Prospecting and mining in the Wild Rogue Wilderness postdate the 1850 's, but most mining occurred prior to 1940 . In the study area, small-scale lode and placer mining and prospecting were stimulated by high gold prices in 1979 . The Mule Mountain, Tina H-Dinawadja, and Mammoth mines (fig. 3 , Nos. $47,34,37)$ were worked in 1980 and 1981 . This work employed eight or more people at least part time in 1981.

The Agness, Mule Creek, Powers, and Galice mining districts include or are near the Wild Rogue Wilderness (fig. 3). Gold and silver production from these districts is summarized in table 1; production figures are probably low because not all production was reported to the U.S. Bureau of Mines. Approximately 341,000 lbs of copper has also been produced from these districts.

More than 800 claims have been staked in or adjacent to the Wild Rogue Wilderness through the years. Approximately one-third of the claims are placer locations. Homestead or mineral patents have been granted at Paradise Bar, Half Moon Bar, Slide Creek Bar, Clay Hill Creek, and Walker Bar (Nos. 57, 59, 81, 72, and 46). Walker Bar has since been reconveyed to the U.S. government. Known mineral properties and mineralized areas in the Wild Rogue Wilderness are shown on figure 3 and described in table 2.

The most significant lode deposits in the wilderness occur along a northeast-trending zone, area B, approximately $0.5 \mathrm{mi}$ wide and $6 \mathrm{mi}$ long. Diorite and abundant quartz-rich dikes and veins permeate gabbroic and hypabyssal volcanic rocks (sheeted dikes). Mineralization is associated with latestage quartz veins. Quartz veins and quartz-vein systems in this terrane are as thick as $12 \mathrm{ft}$ as long as $2,600 \mathrm{ft}$ long. Most quartz veins are lenticular, sheared, cross faulted, and contorted by folding. Some quartz veins and associated shear zones contain gold. Gold content, especially if high, is generally unevenly distributed. Overall minable gold content in mineralized quartz veins is probably 0.01 to $1 \mathrm{oz}$ per ton.

Andesitic to dacitic volcanic rocks, tuff, and coarse agglomeritic flows form a sequence $0.5-2 \mathrm{mi}$ thick, with accompanying mineralization. West and north-northeast of the West Fork of Mule Creek the rocks have been thrust over the Jurassic and Cretaceous Riddle Formation sediments or unconformably underlie Tertiary sedimentary rocks. Stringer mineralization in hydrothermally altered fracture zones that contain little or no quartz are the principal sites of mining activity in the upper Mule Creek area. These zones are as much as several hundred yards thick and several miles long. Pyrite is widely distributed in zones, but chalcopyrite, galena, sphalerite, and magnetite are localized. Laumontite (a zeolite) occurs along some zones as a filling in vesicles. Copper may have been enriched locally as a result of weathering. Brecciated volcanic rocks (stockwork) also contain some mineralization, mainly disseminated pyrite and chalcopyrite, and are typical of the area west-southwest of 
the West Fork of Mule Creek.

The silicic (upper?) part of the volcanic sequence, which exhibits a volumetric increase in pyroclastic rocks and dacite with minor rhyolite dikes, contains several altered mineralized zones. These zones are all interpreted as partly remobilized massive-sulfide pods containing disseminated pyrite, chalcopyrite, bornite, pyrrhotite with copper oxides, and carbonate minerals in weathered argillitic limonitic rock. Most placer gold deposits are in the Mule Creek mining district and adjacent Agness mining district. The placer gold was probably derived from lodes upstream along the Rogue River and from quartz veins at Mule Mountain, Saddle Peaks, Mule Creek, and Pinnacle Point. Placer gold is present in gravel along both Mule Creek and the Rogue River, as well as on stranded river-bench deposits as high as hundreds of yards above creek or river level. Most gravel contains 0.00001 $0.005 \mathrm{oz}$ of gold per cubic yard. Some richer gravel, especially along Mule Creek and at Blossom and Gleason Bars (No. 52), may contain 0.001 to $0.05 \mathrm{oz} / \mathrm{yd}^{3}$ of gold. Average fineness of the gold is about 940; range of fineness for 24 samples is 876 to 989 .

\section{ASSESSMENT OF MINERAL RESOURCE POTENTIAL}

On the basis of a joint investigation by the U.S. Bureau of Mines and U.S. Geological Survey, areas within and immediately adjacent to the Wild Rogue Wilderness have been classified according to their mineral resource potential. Properties with mineral potential and estimated resources of gold and silver are summarized in table 3 and located on figure 3. Figure 4 delineates general areas in the Wild Rogue Wilderness in which there is a potential for various types of mineral deposits.

Based on geologic, geochemical, and geophysical investigations and surveys of mines and prospects in the study area, the potential for the occurrence of lead, zinc, and coal resources are considered low. Mineral deposits that have identifiable resource potential in the Wild Rogue Wilderness include volcanogenic massive sulfides, lode gold, and placer gold. The geologic criteria and mining history favorable for the occurrence of each of these deposits are evaluated below. The wilderness is estimated to contain $3,000 \mathrm{oz}$ of lode gold, $2,000 \mathrm{oz}$ of lode silver and 8500 of placer gold.

The potential for copper, lead, and zinc resources exists in volcanogenic deposits in the form of leached, remobilized massive sulfide deposits in felsic to intermediate volcanic rocks. These small low-grade occurrences are believed to occur at Mt. Bolivar and in an area just north of Saddle Peaks (area $A_{1}$ ).

Gold and silver potential, considered high in the wilderness area, exists as vein gold and silver in quartz veins that are found at the Mammoth, Tina H-Dinawadja, and Mule Mountain mines (fig. 3, Nos. 37, 34, 48; fig. 4, area B). Mule Creek and the Rogue River (area C) contain placer gold.

Low coal potential exists in the Wild Rogue Wilderness Area. Thin seams of shaly coal crop out in the middle Eocene Tyee Formation, which is exposed as an unconformable cap along the northwestern boundary of the wilderness (area D). The major part of the Tyee depositional basin, just north of the wilderness, contains one of the principal coal fields in Oregon and has an estimated resource of 50 million tons of subbituminous and lignitic ranked coal (Brownfield, 1981). Outcrops of significant coal beds, however, do not extend into the wilderness.

\section{Massive Sulfide}

Conditions necessary for the occurrence and mining of mineral resources for copper, zinc, lead, silver and gold in volcanogenic deposits of the Wild Rogue Wilderness (fig. 4, areas $A_{1} A_{1}$, and $A_{2}$ ) are tabulated and evaluated below (see expanded discussion of geology in Gray and others, 1982).
Conditions

Conditions met in Wild Rogue Wilderness?

1. Presence of compositionally

Yes intermediate to felsic calcalkaline volcanic rocks indicative of late-state volcanic activity in a subaqueous island-arc environment for example, pyroclastic rocks interbedded with immature volcaniclastic sedimentary rocks and silicic volcanic rocks).

2. Geochemically anomalous amounts of $\mathrm{Cu}, \mathrm{Zn}, \mathrm{Pb}$, and $\mathrm{Mn}$

in stream sediments.

3. Occurrence of stratabound lenses of pyritic base-metal sulfide in clusters with intragroup spacings of one to several miles.

4. Low-grade dissemination of vein mineralization,and hydrothermal alteration typically stratigraphically lower than stratabound lenses.

5. Abundance of pyroclastic and rhyolitic rocks in the volcanic sequence, usually restricted to the late stages of volcanism in the area.

6. Adequate tonnage and grade.

7. Simple geology with limited No faulting.

8. Easy access and transportation.

9. Ease of underground mining.

Partially

10. Ease of milling and concentration. Flotation would probably work well for concentration.

\section{Lode Gold}

Conditions favorable for the occurrence and mining of mineral resources for lode gold deposits (fig. 4, area B) are evaluated below.

\section{Conditions}

Conditions met in Wild Rogue Wilderness?

1. Occurrence of gold in quartz

Yes veins.

2. Presence of favorable host rocks, including metavolcanic and gabbroic rocks.

3. Presence of rocks broken up by faults along which gold-bearing quartz veins may occur.

4. Presence of quartz veins on the surface with hydrothermal circulation patterns superimposed on host rocks.

5. Copper, silver, gold, and zine geochemical anomalies associated with fractured rocks. 
6. Grades in the range of 2 or

Partially

more ounces gold per ton for small

deposits, 1 or more oz per ton for deposits of 1,000 tons, and 0.5 or more oz per ton for deposits of 50,000 tons. 50,000 tons with $0.5 \mathrm{oz}$ gold per ton probably is near the smallest tonnage and lowest grade feasible for a 15- to 20-person mine, when mined at 50 tons per day (1982 conditions).

7. Ease of underground mining.

Partially

8. Concentration techniques avialable for this type of deposit.

Yes

\section{Placer Fold}

Conditions favorable for the occurrence and estimation of mineral resource potential for placer gold deposits are evaluated below (area $\mathrm{C}$ ).

Conditions

1. Presence of known resources of placer gold.

2. Occurrence of alluvial and river-terrace deposits.

3. Presence of a bedrock source for gold in the headwaters of the stream drainages with alluvial deposits.

4. Grades in the range of at least 0.05 ounce per cubic yard (when mined at $5 \mathrm{yd}^{3}$ per day), or at least 0.005 ounce gold per cubic yard (when mined at $2,000 \mathrm{yd}^{3}$ per day). $2,000 \mathrm{yd}^{3}$ per day at 0.005 ounce gold per $\mathrm{yd}^{3}$ would be near the minimum viable range for a $15-$ to 20-person mine (1982 conditions).

5. Availability of water. Water Yes to work the bench gravel deposits probably would have to be pumped from the Rogue River. Most river-terrace gravel deposits are at least $50 \mathrm{ft}$ above the present river level.

\section{REPERENCES}

Baldwin, E. M., 1969, Thrust faulting along the lower Rogue River, Klamath Mountains, Oregon: Geological Society of America Bulletin, v. 80, no. 10, p. 2047-2052.

1974, Eocene stratigraphy of southwestern Oregon: Oregon Department of Geology and Mineral Industries Bulletin 83, $40 \mathrm{p}$

Baldwin, E. M., and Rud, J. O., 1972, Thrusting of the Rogue Formation near Marial on the lower Rogue River, Oregon: The Ore Bin, v. 34, no. 4, p. 57-66.

Blakely, R. J., and Senior, Lisa, 1983, Map and interpretation of aeromagnetic data for the Wild Rogue Wilderness, Coos and Curry Counties, Oregon: U.S. Geological Survey Miscellaneous Field Studies Map MF-1381-C, scale $1: 48,000$.

Brownfield, M. E., 1981, Oregon's coal and its economic future: Oregon Geology, v. 43, no. 5, p. 63.

Coleman, R.G., 1977, Ophiolites-ancient oceanic lithosphere?: New York, Springer-Verlag, 229p.

Gray, Floyd, and McKee, E. H., 1981, New K-Ar dates from the Wild Rogue Wilderness, southwestern Oregon: Isochron/West, no. 32, p. 27-29.

Gray, Floyd, and Peterson, J. A., 1982, Geochemical analyses of rock and stream-sediment samples from the Wild Rogue Wilderness area, Coos, Curry, and Douglas Counties, Oregon: U.S. Geological Survey Open-File Report 82-186, 20 p.

Gray, Floyd, Ramp, Len, Moring, Barry, Douglas, Ian, and Donahoe, J. L., 1982, Geologic map of the Wild Rogue Wilderness, Coos, Curry, and Douglas Counties, Oregon: U.S. Geological Survey Miscellaneous Field Studies Map MF-1381-A, scale 1:48,000.

Hotz, P.E, 1971, Plutonic rocks of the Klamath Mountains, California and Oregon: U.S. Geological Survey Professional Paper 684-B, 20p.

Irwin, W. $P, 1966$, Geology of the Klamath Mountains Province, in Bailey, E. H., ed., Geology of northern California: California Division of Mines and Geology Bulletin 190, p. 19-38.

Kent, R. C., 1972, The geology of the southeast quarter of the Bone Mountain quadrangle, Oregon: Portland, Oregon, Portland State University, M.S. thesis, 132 p.

Miller, M. S., and Gaps, R. S., 1983, Mineral investigation of Wild Rogue Wilderness: U.S. Bureau of Mines Open-File Report (in press).

Peterman. Z.E., Coleman, R.G. and Bunker, C.M., 1981, Provenance of Eocene graywackes of the Flournoy Formation near Agness, Oregon-A geocheinival approach: Geology, v. 9, no. 2, p. 81-86.

Peterson, Jocelyn. A., and Gray, Floyd, 1983, Geochemical map and rock and stream-sediment data from the Wild Rogue Wilderness, Coos and Curry Counties, Oregon: U.S. Geological Survey Miscellaneous Field Studies Map MF-1381-B, scale 1:48,000。

Purdom, W B., 1977, Guide to the geology and lore of the wild reach of the Rogue River, Oregon: Eugene, University of Oregon Museum of Natural History Bulletin 22, 67p.

Ramp, Len, and Gray, Floyd, 1980, Sheeted dikes of the Wild Rogue Wilderness Oregon: Oregon Geology, v. 42, no. 7, p. 119-124.

Ramp, Len, Schlicker, H. G., and Gray, J. J., 1977, Geology, mineral resources and rock materials of Curry County, Oregon: Oregon Department of Geology and Mineral Industries Bulletin 93, $79 \mathrm{p}$.

Singer, D. A., Cox, D. P., and Drew, L. J., 1975, Grade and tonnage relationships among copper deposits: U.S. Geological Survey Professional Paper 907-A, p. A1-A11.

Turekian, K,K., and Wedepohl, K.H., 1961, Distribution of the elements in some major units of the Earth's crust: Geological Society of Amertica Bulletin, v. 72, no. 2, p. 175-191.

U.S. Geological Survey, 1979, Aeromagnetic map of the Medford area, Oregon: Open-File Report 79-1195, scale $1: 250,000$.

Wells, F.G., 1955, Preliminary geologic map of southwestern Oregon west of meridian $122^{\circ}$ west and south of parallel $43^{\circ}$ north: U.S. Geological Survey Mineral Investigations Field Studies Map MF-38, scale $1: 250,000$.

Wells, F. G., and Peck, D. L., 1961, Geologic map of Oregon west of the 121st meridian: U.S. Geological Survey Miscellaneous Investigations Map I-325, scale 1:500,000.

Wells, F. G., and Walker, G. W., 1953, Geology of the Galice quadrangle, Oregon: U.S. Geological Survey Geologic Quadrangle Map GQ-25, scale 1:62,500. 
Table 1.--Gold and silver production from mining districts that are in or near the the Wild Rogue Wilderness, Oregon

[Data are from the U.S. Bureau of Mines historical-production files and represent voluntary submittals from the mining industry. These data are not comparable to data developed during this study]

\begin{tabular}{lcccc}
\hline & Agness & Mule Creek & Powers & Galice \\
\hline Gold (troy ounces) & & & & \\
$\quad$ Lode & 65 & 143 & 170 & 29,486 \\
$\quad$ Placer & 421 & 975 & 785 & 15,425 \\
\hline Silver (troy ounces) & & & & \\
$\quad$ Lode & 14 & 22 & 361 & 51,664 \\
Placer & 301 & 64 & 88 & 1,648 \\
\hline
\end{tabular}

Table 3.--Estimates of indicated mineral resources in or near the wild Rogue wilderness, oregon

[w, withheld; --, unknown or unestimated. Totals include estimates for withheld data]

\begin{tabular}{|c|c|c|c|c|c|c|c|c|c|c|c|c|}
\hline \multirow{2}{*}{$\begin{array}{l}\text { Map } \\
\text { No. }\end{array}$} & \multirow{2}{*}{ Name } & \multirow{2}{*}{ Commodity } & \multirow{2}{*}{$\begin{array}{l}\text { Type of } \\
\text { deposit or } \\
\text { occurrence }\end{array}$} & \multirow{2}{*}{ Description } & \multicolumn{3}{|c|}{ Placer gold } & \multicolumn{3}{|c|}{ Lode gold } & \multicolumn{2}{|c|}{ Silver } \\
\hline & & & & & Cubic yds & Troy oz $/ \mathrm{yd}^{3}$ & Troy oz & Short tons & Troy $o z / t$ & Troy oz & Troy $o z / t$ & Troy oz \\
\hline 52 & $\begin{array}{l}\text { Blossom and } \\
\text { Gleason Bars, }\end{array}$ & Gold & Placer & Bench gravel & 260,000 & 0.0016 & 416 & -- & -- & -- & -- & - \\
\hline 2 & $\begin{array}{l}\text { Bolivar } \\
\text { (Fuller). }\end{array}$ & Copper & Lode & $\begin{array}{l}\text { Sheared veins and weathered } \\
\text { secondary deposits. An } \\
\text { inferred } 30,000 \text { short tons } \\
\text { contain about } 5 \text { percent } \\
\text { copper. }\end{array}$ & -- & - & -- & -- & -- & -- & -- & -- \\
\hline 65 & Brushy Bar. & Gold & Placer & Bench gravel & $1,200,000$ & .0005 & 600 & - & -- & -- & -- & -- \\
\hline 73 & $\begin{array}{l}\text { Clay Hill } \\
\text { Bar. }\end{array}$ & Gold & Placer & Bench gravel & $w$ & -- & -- & -- & -- & -- & -- & -- \\
\hline 59 & $\begin{array}{l}\text { Half Mon } \\
\text { Bar. }\end{array}$ & Gold & Placer & Bench gravel & พ & -- & -- & -- & -- & -- & $\rightarrow$ & -- \\
\hline 79 & $\begin{array}{l}\text { Hicks Creek } \\
\text { Bar. }\end{array}$ & Gold & Placer & Bench gravel & 800,000 & .0003 & 240 & -- & -- & -- & - & - \\
\hline 37 & $\begin{array}{l}\text { Mammoth } \\
\text { (Gloria). }\end{array}$ & Gold & Lode & $\begin{array}{l}\text { Quartz veins and sheared } \\
\text { zones. }\end{array}$ & -- & -- & -- & 1,000 & 0.76 & 760 & 0.2 & 200 \\
\hline 38 & $\begin{array}{l}\text { Mule Creek } \\
\text { Placers. }\end{array}$ & Gold & Placer & $\begin{array}{l}\text { Modern-day and bench placer } \\
\text { deposit. }\end{array}$ & $w$ & -- & -- & -- & -- & - & -- & - \\
\hline 48 & Mule Mountain. & Gold & Lode & $\begin{array}{l}\text { Quartz veins and sheared } \\
\text { zones. }\end{array}$ & -- & -- & -- & 20,000 & 0.1 & 2,000 & 0.07 & 1,400 \\
\hline 67 & $\begin{array}{l}\text { North } \\
\text { Solitude Bar. }\end{array}$ & Gold & Placer & Bench gravel & 240,000 & .001 & 240 & -- & - & -- & -- & -- \\
\hline 57 & Paradise Bar, & Gold & Placer & Bench gravel & $w$ & $-\infty$ & - & -- & - & $\rightarrow$ & -- & -- \\
\hline 62 & $\begin{array}{l}\text { Recent Rogue } \\
\text { River. }\end{array}$ & Gold & Placer & Recent gravel & $3,000,000$ & .0005 & 1,500 & -- & -- & -- & -- & - \\
\hline 81 & $\begin{array}{l}\text { Slide Creek } \\
\text { Bar. }\end{array}$ & Gold & Placer & Bench gravel & w & -- & -- & -- & -- & -- & -- & -- \\
\hline 74 & $\begin{array}{l}\text { South Clay } \\
\text { Hill Point. }\end{array}$ & Gold & Placer & Bench gravel & 30,000 & .00003 & 0.9 & - & -- & -- & -- & -- \\
\hline 66 & $\begin{array}{l}\text { South } \\
\text { Solitude Bar, }\end{array}$ & Gold & Placer & Bench gravel & $1,800,000$ & .0002 & 360 & -- & -- & -- & -- & -- \\
\hline 71 & $\begin{array}{l}\text { Tacoma } \\
\text { Rapids Bar. }\end{array}$ & Gold & Placer & Bench gravel & 90,000 & .002 & 180 & -- & -- & -- & -- & -- \\
\hline 70 & $\begin{array}{l}\text { Tate Creek } \\
\text { Bar. }\end{array}$ & Gold & Placer & Bench gravel & 480,000 & .0002 & 96 & -- & -- & - & -- & -- \\
\hline 34 & $\begin{array}{l}\text { Tina H- } \\
\text { Dinawadja } \\
\text { lold Serpentine }\end{array}$ & $\begin{array}{l}\text { Gold } \\
\text { e) }\end{array}$ & Lode & $\begin{array}{l}\text { Quartz veins and sheared } \\
\text { zones. }\end{array}$ & -- & - & -- & 600 & .349 & 200 & 0.6 & 360 \\
\hline 46 & Walker Bar. & Gold & Placer & Bench gravel & 650,000 & .0007 & 455 & - & - & -- & -- & -- \\
\hline & TOTAL & & & & $13,000,000$ & -- & $8,517.9$ & 21,600 & -- & 2,960 & -- & 1,960 \\
\hline
\end{tabular}


Table 2.--Known mineral porperties of the Wild Rogue Wilderness, Oregon

[L, lode; $P$, placer; W, withheld for owner confidentiality]

\begin{tabular}{|c|c|c|c|}
\hline $\begin{array}{l}\text { Map } \\
\text { number }\end{array}$ & Property name & Workings & Resource data \\
\hline 1 & $\begin{array}{l}\text { West Fork Cow Creek } \\
\text { (P) }\end{array}$ & Pits and trenches & $\begin{array}{l}\text { Recent and bench gravel. Probably some gold } \\
\text { resources because of past production. Two } \\
\text { panned samples contained no detectable } \\
\text { gold. }\end{array}$ \\
\hline 2 & $\begin{array}{l}\text { Bolivar mine (L) } \\
\quad \text { (outside study area) }\end{array}$ & $\begin{array}{l}\text { Caved adits, pits, and } \\
\text { trenches }\end{array}$ & $\begin{array}{l}\text { Copper sulfides, oxides, and carbonate } \\
\text { minerals in sheared lenticular veins and } \\
\text { joints. At least } 26,000 \text { lbs of copper } \\
\text { produced, and estimated resources of } \\
30,000 \text { short tons containing } 5 \text { percent } \\
\text { copper }\end{array}$ \\
\hline 3 & Bolivar Creek (P) & None & $\begin{array}{l}\text { Recent and bench gravel. Four panned } \\
\text { samples contained no detectable gold. }\end{array}$ \\
\hline 4 & Unknown (L) & $\begin{array}{l}\text { Bulldozer trenches and } \\
\text { roads }\end{array}$ & $\begin{array}{l}\text { Limonitic weathered metavolcanic and } \\
\text { sedimentary rocks. Six samples contained } \\
\text { as much as } 0.01 \mathrm{oz} \text { gold/ton, } 0.2 \text { percent } \\
\text { copper, and } 0.0125 \text { percent zinc. }\end{array}$ \\
\hline 5 & Unknown (L) & One pit (?) & $\begin{array}{l}\text { Overburden, probably metavolcanic rocks. } \\
\text { Two samples contained as much as trace } \\
\text { gold, } 0.2 \text { oz silver/ton, and } 0.012 \text { percent } \\
\text { copper. }\end{array}$ \\
\hline 6 & Unknown (L) & $\begin{array}{l}\text { Adit about } 145 \mathrm{ft} \\
\text { long and small } \\
\text { pit }\end{array}$ & $\begin{array}{l}\text { Porphyritic metavolcanic rocks irregularly } \\
\text { veined by white zeolite minerals. Seven } \\
\text { samples contained as much as trace gold, } \\
0.2 \mathrm{oz} \text { silver/ton, and } 0.087 \text { percent } \\
\text { copper. }\end{array}$ \\
\hline 7 & Unknown（L) & Small quarry & $\begin{array}{l}\text { Contact of greenstone and sedimentary rocks, } \\
\text { intensely fractured and sheared. } \\
\text { Greenstone contains some pyrite and copper } \\
\text { sulfides. A sample contained trace gold, } \\
0.1 \mathrm{oz} \text { silver/ton, and } 0.011 \text { percent } \\
\text { copper. }\end{array}$ \\
\hline 8 & Foggy Creek (P) & None & $\begin{array}{l}\text { Recent and bench gravel. Probably some gold } \\
\text { resources, although five placer samples } \\
\text { contained no detectable gold. }\end{array}$ \\
\hline 9 & Unknown (L) & Three small pits & $\begin{array}{l}\text { Limonitic weathered porphyritic greenstone } \\
\text { irregularly veined by zeolite minerals. } \\
\text { Two samples contained as much as trace } \\
\text { gold and } 0.007 \text { percent copper. }\end{array}$ \\
\hline 10 & Unknown (L) & One small pit & $\begin{array}{l}\text { Weathered veined coarse basaltic } \\
\text { metavolcanic rocks. A sample contained } \\
\text { trace gold and silver and } 0.012 \text { percent } \\
\text { copper. }\end{array}$ \\
\hline 11 & Unknown (L) & None & $\begin{array}{l}\text { Contact of greenstone and black shale. } \\
\text { Three samples contained as much as } 0.1 \mathrm{oz} \\
\text { gold/ton, } 0.1 \mathrm{oz} \text { silver, and } 0.018 \text { percent } \\
\text { copper. }\end{array}$ \\
\hline 12 & Unknown (L) & Two small pits & $\begin{array}{l}\text { Limonitic weathered porphyritic metavolcanic } \\
\text { rocks, some vein quartz. Two samples } \\
\text { contained as much as trace gold, } 0.1 \text { oz } \\
\text { silver/ton, and } 0.011 \text { percent copper. }\end{array}$ \\
\hline 13 & $\begin{array}{l}\text { Golden Goose-Mary- } \\
\text { Naomi (L) }\end{array}$ & None & $\begin{array}{l}\text { Altered sheared slightly quartzose pyritic } \\
\text { greenstone. Three samples contained a } \\
\text { maximum of } 0.4 \mathrm{oz} \text { silver/ton. }\end{array}$ \\
\hline 14 & Yankee Boys 1, 2 (L) & A short inclined shaft & $\begin{array}{l}\text { Altered pyritic greenstone. Eight samples } \\
\text { contained a maximum of trace gold and } \\
0.4 \mathrm{oz} \text { silver/ton. }\end{array}$ \\
\hline 15 & Red Blanket (L) & None & $\begin{array}{l}\text { Limonitic weathered sheared pyritic zones in } \\
\text { greenstone; minor chalcopyrite. Seven } \\
\text { samples contained a maximum of trace gold } \\
\text { and } 0.04 \mathrm{oz} \text { silver/ton. }\end{array}$ \\
\hline 16 & Underslide (L) & Small pits & $\begin{array}{l}\text { Altered sheared zone in greenstone. Three } \\
\text { samples contained less than } 0.005 \mathrm{oz} \text { gold } \\
\text { per ton and less than } 0.2 \text { oz silver/ton. }\end{array}$ \\
\hline
\end{tabular}


Table 2.--Known mineral porperties of the Wild Rogue Wilderness, Oregon--Continued

\begin{tabular}{|c|c|c|c|}
\hline $\begin{array}{l}\text { Map } \\
\text { number }\end{array}$ & Property name & Workings & Resource data \\
\hline 17 & Paradise mine (L) & $\begin{array}{l}\text { Two adits are } 166 \mathrm{ft} \\
\text { and } 258.5 \mathrm{ft} \text { long }\end{array}$ & $\begin{array}{l}\text { A quartzose sheared zone in greenstone. } \\
\text { Sixteen samples contained a maximum of } \\
0.01 \mathrm{oz} \text { gold/ton and a maximum of } 0.2 \mathrm{oz} \\
\text { silver/ton. }\end{array}$ \\
\hline 18 & Camp Hope (L) & Small trenches, pits & $\begin{array}{l}\text { Shaly metasedimentary rocks. Two samples } \\
\text { contained traces of gold and silver. }\end{array}$ \\
\hline 19 & North Hope (L) & $\begin{array}{l}\text { Trench about } 25 \mathrm{ft} \\
\text { long }\end{array}$ & $\begin{array}{l}\text { Contact of greenstone and metasedimentary } \\
\text { rocks. Five samples contained as much as } \\
0.01 \mathrm{oz} \text { gold/ton and } 0.13 \mathrm{oz} \mathrm{silver/ton.}\end{array}$ \\
\hline 20 & West Hope (L) & $\begin{array}{l}\text { Pits, trenches, and } \\
\text { three short adits } \\
\text { that total } 77 \mathrm{ft} .\end{array}$ & $\begin{array}{l}\text { Fractured altered limonitic greenstone. } \\
\text { Sixteen samples contained trace gold, } \\
\text { and as much as } 0.2 \text { oz silver/ton. }\end{array}$ \\
\hline 21 & Wild Hog (L) & $\begin{array}{l}\text { Caved } 30-f \text { t long } \\
\text { trench }\end{array}$ & $\begin{array}{l}\text { Greenstone talus, some conglomerate. Two } \\
\text { samples contained trace gold and as much } \\
\text { as } 0.2 \text { oz silver/ton. }\end{array}$ \\
\hline 22 & Hanging Rock (L) & $\begin{array}{l}\text { Bulldozer road and } \\
\text { trench }\end{array}$ & $\begin{array}{l}\text { Altered greenstone, mostly covered by talus. } \\
\text { A sample contained } 0.1 \mathrm{oz} \text { silver/ton. }\end{array}$ \\
\hline 23 & South Ridge (L) & Small trench & $\begin{array}{l}\text { Altered greenstone; some mafic dikes; some } \\
\text { sheared fractured rocks. Two samples } \\
\text { contained as much as } 0.002 \text { oz of gold/ton } \\
\text { and } 0.002 \text { oz of silver/ton. }\end{array}$ \\
\hline 24 & Old Red mine (L) & $\begin{array}{l}\text { Bulldozer roads, } \\
\text { trenches, pits, a } \\
\text { short inclined shaft }\end{array}$ & $\begin{array}{l}\text { Sheared siliceous zones in greenstone. One } \\
\text { of } 21 \text { samples contained } 0.51 \mathrm{oz} \text { gold/ton. } \\
\text { Another contained } 0.4 \mathrm{oz} \text { gold/ton. The } \\
\text { rest contained up to } 0.11 \mathrm{oz} \text { gold/ton. } \\
\text { One sample contained } 6.3 \text {, and one } 2.5 \mathrm{oz} \\
\text { silver/ton and the rest averaged } 0.275 \mathrm{oz} \\
\text { silver/ton. Average copper content was } \\
0.089 \text { percent; average lead content was } \\
0.36 \text { percent, and average zinc content was } \\
0.52 \text { percent. }\end{array}$ \\
\hline 25 & Alpine (L) & $\begin{array}{l}\text { Small pits, trenches, } \\
\text { and two short adits }\end{array}$ & $\begin{array}{l}\text { Metavolcanic rocks with altered sheared } \\
\text { zones and joints. Laumontite along some } \\
\text { discontinuities. Six samples contained a } \\
\text { maximum of } 0.06 \text { oz gold/ton, } 0.4 \text { oz } \\
\text { silver/ton, } 0.84 \text { percent lead and } 0.017 \\
\text { percent copper. }\end{array}$ \\
\hline 26 & Unknown (L) & Small pits and trenches & $\begin{array}{l}\text { Limonitic altered metavolcanic rock. of } \\
\text { eight samples, two contained } 0.52 \text { and } 0.18 \\
\text { oz gold/ton but the rest contained trace } \\
\text { or less gold. Average silver content was } \\
0.36 \mathrm{oz} \text { per ton. }\end{array}$ \\
\hline 27 & $\begin{array}{l}\text { Golden Fraetion or } \\
\text { Sabbath Day (L) }\end{array}$ & Caved adit & $\begin{array}{l}\text { Greenstone with weathered sulfides. A grab } \\
\text { sample from the dump contained } 0.21 \mathrm{oz} \\
\text { gold/ton and } 0.2 \mathrm{oz} \text { silver/ton. }\end{array}$ \\
\hline 28 & Unknown (L) & None & $\begin{array}{l}\text { Intensely fractured, weathered greenstone. } \\
\text { A sample contained trace gold, } 0.2 \mathrm{oz} \\
\text { silver/ton, and } 0.011 \text { percent copper. }\end{array}$ \\
\hline 29 & Golden Cabin (L) & $\begin{array}{l}\text { Adit less than } 15 \mathrm{ft} \\
\text { long and } 3 \text { trenches } \\
\text { trenches } 10 \text { to } 15 \mathrm{ft} \\
\text { long }\end{array}$ & $\begin{array}{l}\text { Greenstone, some brecciated; less than } 5 \\
\text { percent quartz and pyrite. Four samples } \\
\text { contained as much as trace gold, trace } \\
\text { silver, and } 0.01 \text { percent copper. }\end{array}$ \\
\hline 30 & Unknown (L) & Small pit & $\begin{array}{l}\text { Amygdaloidal slightly silicified } \\
\text { metavolcanic rocks. A sample contained } \\
\text { trace gold and } 0.018 \text { percent copper. }\end{array}$ \\
\hline 31 & Unknown (L) & Two small pits & $\begin{array}{l}\text { Weathered metavolcanic rocks with quartz } \\
\text { veins and other white vein minerals; some } \\
\text { sulfides. Two samples contained trace } \\
\text { gold and as much as } 0.022 \text { percent copper. }\end{array}$ \\
\hline 32 & Unknown (L) & $\begin{array}{l}\text { Seven small pits along } \\
270 \mathrm{ft} \text { of the } \\
\text { zone }\end{array}$ & $\begin{array}{l}\text { Altered sheared quartzose zone in } \\
\text { greenstone. Six samples contained as much } \\
\text { as trace gold, } 0.1 \text { oz silver/ton and } 0.22 \\
\text { percent copper. Average copper content } \\
\text { was } 0.08 \text { percent. }\end{array}$ \\
\hline
\end{tabular}


Table 2.--Known mineral porperties of the Wild Rogue Wilderness, Oregon--Continued

\begin{tabular}{|c|c|c|c|}
\hline $\begin{array}{l}\text { Map } \\
\text { number }\end{array}$ & Property name & Workings & Resource data \\
\hline 33 & Donahue $(\mathrm{L})$ & $\begin{array}{l}\text { A few small pits and } \\
\text { trenches }\end{array}$ & $\begin{array}{l}\text { Greenstone with thin quartz veins. Two } \\
\text { samples contained a maximum of trace gold } \\
\text { and } 0.2 \text { oz silver/ton. }\end{array}$ \\
\hline 34 & $\begin{array}{l}\text { Tina H-Dinawadja } \\
\text { mines (L) }\end{array}$ & $\begin{array}{l}\text { Five adits which total } \\
\text { about } 700 \mathrm{ft} \text {, one } \\
\text { caved adit, and } \\
\text { one inaccessible adit } \\
\text { in a cliff face }\end{array}$ & $\begin{array}{l}\text { Altered sheared greenstone and quartz veins. } \\
\text { At least } \$ 48,000 \text { of gold produced. } \\
\text { Estimated resources of } 600 \text { tons containing } \\
0.349 \text { oz gold/ton and } 0.6 \text { oz silver/ton. }\end{array}$ \\
\hline 35 & Unknown (L) & Small pit & $\begin{array}{l}\text { Fractured weathered metavolcanic rocks. A } \\
\text { sample contained trace gold, } 0.221 \text { percent } \\
\text { copper, } 0.15 \text { percent zinc, and } 0.009 \\
\text { percent lead. }\end{array}$ \\
\hline 36 & Borden (L) & Small caved pits & $\begin{array}{l}\text { Greenstone. Two samples contained a maximum } \\
\text { of trace gold and } 0.2 \mathrm{oz} \text { silver/ton. }\end{array}$ \\
\hline 37 & Mammoth mine (L) & $\begin{array}{l}\text { Two adits which total } \\
355 \mathrm{ft} \text { long, and } \\
3 \text { pits }\end{array}$ & $\begin{array}{l}\text { Quartz veins in greenstone. Estimated } \\
\text { resources of } 1,000 \text { tons containing } \\
0.76 \mathrm{oz} \text { gold/ton and } 0.2 \mathrm{oz} \text { silver/ton. }\end{array}$ \\
\hline 38 & Mule Creek (P) & $\begin{array}{l}\text { Small trenches, pits, } \\
\text { ditches, and } \\
\text { hydraulically } \\
\text { overturned workings }\end{array}$ & $\begin{array}{l}\text { At least } 4.28 \mathrm{oz} \text { gold produced from the West } \\
\text { Fork. Less than } 100,000 \mathrm{yd}^{3} \text { contains less } \\
\text { than } 0.02 \mathrm{oz} \text { gold } / \mathrm{yd}^{3} \text {. }\end{array}$ \\
\hline 39 & Unknown (L) & Small pit (?) & $\begin{array}{l}\text { Limonitic greenstone. A sample contained } \\
0.01 \mathrm{oz} \text { gold/ton and } 0.01 \mathrm{oz} \text { silver/ton. }\end{array}$ \\
\hline 40 & Blue Bird (L) & $\begin{array}{l}\text { Several small pits and } \\
\text { short adits, some } \\
\text { caved }\end{array}$ & $\begin{array}{l}\text { Altered sheared quartzose volcanic rocks. } \\
\text { Eight samples contained as much as } 0.28 \\
\text { percent copper, } 0.053 \mathrm{oz} \text { silver/ton, and } \\
0.006 \mathrm{oz} \text { gold/ton. }\end{array}$ \\
\hline 41 & $\begin{array}{l}\text { Anderson Ranch } \\
\text { Bar (P) }\end{array}$ & $\begin{array}{l}\text { Small trenches and pits } \\
\text { possibly hydraulic } \\
\text { workings }\end{array}$ & $\begin{array}{l}\text { Bench gravel at mouth of Mule Creek. } \\
\text { Thirteen placer samples contained an } \\
\text { average of } 0.00007 \mathrm{oz} \text { gold/yd }\end{array}$ \\
\hline 42 & Victor 1 and 2 (L) & $\begin{array}{l}\text { Two subsurface workings } \\
41.5 \mathrm{ft} \text { and } 78.5 \mathrm{ft} \\
\text { long, and small pits }\end{array}$ & $\begin{array}{l}\text { Sheared altered zone in greenstone; minor } \\
\text { quartz. of } 11 \text { samples, greatest silver } \\
\text { content was } 0.2 \mathrm{oz} / \text { ton. Trace } \\
\text { gold and as much as } 0.016 \text { percent copper } \\
\text { were contained in the samples. }\end{array}$ \\
\hline 43 & Rocky Bar Creek (P) & None & $\begin{array}{l}\text { Recent creek gravels and small bench gravel } \\
\text { deposits. A placer sample contained } \\
0.00014 \text { oz gold/yd }\end{array}$ \\
\hline 44 & $\begin{array}{l}\text { North Mule Mountain } \\
\text { (L) }\end{array}$ & Small pit & $\begin{array}{l}\text { Alaskitic pegmatite in greenstone. One } \\
\text { sample contained a trace of gold. }\end{array}$ \\
\hline 45 & Marial Bar (P) & Large hydraulic working & $\begin{array}{l}\text { Bench gravel mostly mined out. Five placer } \\
\text { samples contained an average of } 0.0002 \mathrm{oz} \\
\text { gold/yd. }\end{array}$ \\
\hline 46 & Walker Bar (P) & $\begin{array}{l}\text { Trenches and } \\
\text { hydraulic workings }\end{array}$ & $\begin{array}{l}\text { Bench gravel production of at least } 41.313^{\mathrm{oz}} \\
\text { gold. Estimated resource of } 650,000 \mathrm{yd} \\
\text { containing } 0.0007 \mathrm{oz} \text { gold } / \mathrm{yd}^{3 .}\end{array}$ \\
\hline 47 & $\begin{array}{l}\text { Mule Mountain mine } \\
\text { (L) }\end{array}$ & $\begin{array}{l}\text { At least } 800 \mathrm{ft} \text { of } \\
\text { underground workings }\end{array}$ & $\begin{array}{l}\text { Quartz veins in greenstone. At least } 94.75 \\
\text { oz of gold and } 8 \text { oz of silver produced. } \\
\text { Resources of } 20,000 \text { tons are estimated to } \\
\text { contain } 0.1 \text { oz gold/ton and } 0.07 \mathrm{oz} \\
\text { silver/ton. }\end{array}$ \\
\hline 48 & Burns Creek (L) & Small pits & $\begin{array}{l}\text { Metavolcanic rocks, some altered. Three } \\
\text { samples each contained less than } 0.005 \mathrm{oz} \\
\text { gold/ton and less than } 0.2 \mathrm{oz} \text { silver/ton. }\end{array}$ \\
\hline 49 & Quo Vadis mine (L) & $\begin{array}{l}\text { Adit about } 614 \mathrm{ft} \\
\text { long }\end{array}$ & $\begin{array}{l}\text { A sheared quartz vein in greenstone. } \\
\text { Fifteen samples contained an average of } \\
0.1 \mathrm{oz} \text { gold/ton and an average of } 0.09 \mathrm{oz} \\
\text { silver/ton. }\end{array}$ \\
\hline 50 & Milner No. 1 (L) & $\begin{array}{l}\text { 126.5-ft adit and } \\
\text { drift; small pit }\end{array}$ & $\begin{array}{l}\text { Quartzose sheared zone in greenstone. } \\
\text { Twelve samples contained as much as } \\
0.01 \mathrm{oz} \text { gold/ton, } 0.3 \mathrm{oz} \text { silver/ton, and } \\
0.17 \text { percent copper. }\end{array}$ \\
\hline
\end{tabular}


Table 2.--Known mineral porperties of the Wild Rogue Wilderness, Oregon--Continued

\begin{tabular}{|c|c|c|c|}
\hline $\begin{array}{l}\text { Map } \\
\text { number }\end{array}$ & Property name & Workings & Resource data \\
\hline 51 & Keystone mine (L) & $\begin{array}{l}\text { Three adits which total } \\
179 \mathrm{ft} \text {, and several } \\
\text { small surface } \\
\text { excavations }\end{array}$ & $\begin{array}{l}\text { Quartz vein system in greenstone. Quartz } \\
\text { veins as much as } 3 \mathrm{ft} \text { thick along } \\
\text { a zone about } 700 \mathrm{ft} \text { long. Seven } \\
\text { samples contained an average of } 0.6 \mathrm{oz} \\
\text { gold/ton and } 0.15 \mathrm{oz} \text { silver/ton. }\end{array}$ \\
\hline 52 & $\begin{array}{l}\text { Blossom and Gleason } \\
\text { Bars (P) }\end{array}$ & $\begin{array}{l}\text { Hydraulic pits and } \\
\text { trenches }\end{array}$ & $\begin{array}{l}\text { Estimated } 40,000 \mathrm{yd}^{3} \text { gravel } \\
\text { mined. Resources estimated at } 210,000 \mathrm{yd}^{3} \\
\text { with } 0.002 \text { oz gol } \mathrm{d}^{3} / \mathrm{yd}^{3}, 3,500 \mathrm{yd}^{3} \text { with } \\
0.004 \mathrm{oz} \text { gold } \mathrm{yd}^{3} \text { and } 45,000 \mathrm{yd}^{3} \text { with } \\
0.0001 \mathrm{oz} \mathrm{gold} / \mathrm{yd}^{3} \text {. }\end{array}$ \\
\hline 53 & $\begin{array}{l}\text { Blossom and Gleason } \\
\text { Bars (L) }\end{array}$ & $\begin{array}{l}\text { Four short adits, } \\
\text { one flooded }\end{array}$ & $\begin{array}{l}\text { Shear zones in greenstone are at least } 10 \mathrm{ft} \\
\text { thick, and at least } 100 \mathrm{ft} \text { long, and } \\
\text { contain pyrite. An argillitized shear } \\
\text { zone extends up Burns Creek. Of } 30 \text { samples } \\
\text { taken, } 25 \text { contained up to } 0.01 \mathrm{oz} \\
\text { gold/ton. One sample contained } 0.068 \mathrm{oz} \\
\text { gold/ton and maximum silver content was } \\
0.6 \mathrm{oz} / \text { ton. Maximum copper content was } \\
0.184 \text { percent. }\end{array}$ \\
\hline 54 & Burns Creek (P) & None & $\begin{array}{l}\text { Modern-day and bench gravel from an area of } \\
\text { sedimentary rocks, sheared altered rocks, } \\
\text { and greenstone. One panned sample } \\
\text { contained one very fine gold flake another } \\
\text { contained no detectable gold. }\end{array}$ \\
\hline 55 & Blossom Bar Creek (P) & None & $\begin{array}{l}\text { Modern-day and bench gravel from an area of } \\
\text { sedimentary rocks, some sheared altered } \\
\text { rocks, and some greenstone. No detectable } \\
\text { gold was found in three panned samples. }\end{array}$ \\
\hline 56 & Paradise Creek (P) & None & $\begin{array}{l}\text { Modern-day and bench gravel from an area of } \\
\text { sedimentary rocks and minor greenstone. A } \\
\text { panned sample contained no detectable } \\
\text { gold. }\end{array}$ \\
\hline 57 & Paradise Bar (P) & W & W \\
\hline 58 & Jackson Creek (P) & None & $\begin{array}{l}\text { Modern-day and bench gravel from an area of } \\
\text { sedimentary rocks. A panned sample from } \\
\text { near the water intake to Paradise Bar } \\
\text { Lodge contained no detectable gold. Three } \\
\text { panned samples from near the bridge over } \\
\text { Jackson Creek contained } 0.0000047 \text { - } \\
0.000019 \text { oz gold/yd } 3 \text {. }\end{array}$ \\
\hline 59 & Half Moon Bar (P) & W & W \\
\hline 60 & Devils Backbone (L) & Small pits & $\begin{array}{l}\text { Pyrite and chalcopyrite in greenstone and } \\
\text { hornfels(?). Of five samples, one } \\
\text { contained } 0.05 \text { oz gold/ton. Two contained } \\
0.11 \text { and } 0.59 \text { percent copper. }\end{array}$ \\
\hline 61 & Sly Fox (L) & $\begin{array}{l}\text { Small pits and a very } \\
\text { short adit }\end{array}$ & $\begin{array}{l}\text { Limonitic weathered siliceous zone in } \\
\text { greenstone. Two samples contained } 0.04 \\
\text { and } 0.07 \mathrm{oz} \text { gold/ton, and } 1.4 \mathrm{oz} \\
\text { silver/ton. }\end{array}$ \\
\hline 62 & Recent Rogue River (P) & $\begin{array}{l}\text { Probable workings along } \\
\text { river }\end{array}$ & $\begin{array}{l}\text { Estimated resources of } 3,000,000 \mathrm{yd}^{3} \\
\text { containing } 0.0005 \text { oz gold } / \mathrm{yd}^{3} \text {. }\end{array}$ \\
\hline 63 & East Creek (P) & None & $\begin{array}{l}\text { Modern-day gravel and small bench gravel } \\
\text { deposits. Two placer samples contained no } \\
\text { detectable gold. }\end{array}$ \\
\hline 64 & Brushy Bar Creek (P) & None & $\begin{array}{l}\text { Modern-day and bench gravel from an area of } \\
\text { sedimentary rocks. A panned sample } \\
\text { contained no detestable gold. }\end{array}$ \\
\hline 65 & Brushy Bar (P) & $\begin{array}{l}\text { Ditches, trenches, } \\
\text { and pits }\end{array}$ & $\begin{array}{l}\text { Estimated } 45,000 \mathrm{yd}^{3} \text { gravel mined. } \\
\text { Resources of at least } 1,200,000 \mathrm{yd}^{3} \\
\text { estimated. Gravel estimated to contain } \\
0.0005 \mathrm{oz} \text { gold } / \mathrm{yd}^{3} \text {. }\end{array}$ \\
\hline 66 & $\begin{array}{l}\text { South Soldtude } \\
\text { Bar (P) }\end{array}$ & $\begin{array}{l}\text { Pits, trenches, and } \\
\text { hydraulic workings }\end{array}$ & $\begin{array}{l}\text { Estimated } 140,000 \mathrm{yd}^{3} \text { gravel mined } \\
\text { and resources of } 1,800,000 \mathrm{yd}^{3} \text { containing } \\
0.0002 \mathrm{oz} \text { gold } / \mathrm{yd}^{3} \text {. }\end{array}$ \\
\hline
\end{tabular}


Table 2.--Known mineral porperties of the Wild Rogue Wilderness, Oregon--Continued

\begin{tabular}{|c|c|c|c|}
\hline $\begin{array}{l}\text { Map } \\
\text { number }\end{array}$ & Property name & Workings & Resource data \\
\hline 67 & $\begin{array}{l}\text { North Solitude } \\
\text { Bar (P) }\end{array}$ & $\begin{array}{l}\text { Pits, trenches, ditches, } \\
\text { and hydraulicked } \\
\text { workings }\end{array}$ & $\begin{array}{l}\text { Bench placer. Estimated production of abqut } \\
70,000 \mathrm{yd}^{3} \text { containing } 0.0003 \mathrm{ox} \text { gold } / \mathrm{yd}^{3} \\
\text { and } 20,000 \mathrm{yd}^{3} \text { containing } 0.0001 \mathrm{oz} \\
\text { gol } \mathrm{d} / \mathrm{yd}^{3} \text {. Estimated resources ąre } 240,000 \\
\mathrm{yd}^{3} \text { containing } 0.001 \text { oz gold } / \mathrm{yd}^{3} \text {. }\end{array}$ \\
\hline 68 & $\begin{array}{l}\text { North Solitude } \\
\text { Bar (L) }\end{array}$ & Two small pits & $\begin{array}{l}\text { Sheared pyritic lenses in greenstone are a } \\
\text { few feet thick and at least } 100 \mathrm{ft} \text { long. } \\
\text { Four samples contained, at most, a trace } \\
\text { of silver. }\end{array}$ \\
\hline 69 & Tate Creek (P) & None & $\begin{array}{l}\text { Modern-day and bench gravel derived from } \\
\text { sedimentary rocks. A panned sample } \\
\text { contained } 0.0000079 \text { oz gold/yd }\end{array}$ \\
\hline 70 & Tate Creek Bar (P) & $\begin{array}{l}\text { Pits, trenches, and } \\
\text { ditches }\end{array}$ & $\begin{array}{l}\text { Bench gravel. Estimated production of } \\
15,000 \mathrm{yd} 3^{3} \text { and resources of } 480,000 \mathrm{yd}^{3} \\
\text { containing } 0.0002 \mathrm{oz} \mathrm{gold} / \mathrm{yd}^{3} \text {. }\end{array}$ \\
\hline 71 & $\begin{array}{l}\text { Tacoma Rapids Bar } \\
\text { (P) }\end{array}$ & $\begin{array}{l}\text { Ditches or gulches } \\
15 \text { to } 30 \mathrm{ft} \\
\text { wide }\end{array}$ & $\begin{array}{l}\text { Bench gravel. } 10.01 \text { oz gold in } \\
1912 \text { and } 2.59 \text { oz gold in } 1935 \\
\text { produced from this area. Estimated } \\
\text { resource of } 90,000 \mathrm{yd}^{3} \text { containing } 0.002 \mathrm{oz} \\
\text { gold } / \mathrm{yd}^{3} \text {. }\end{array}$ \\
\hline 72 & Clay Hill Creek (P) & w & $w$ \\
\hline 73 & Clay Hill Bar (P) & W & W \\
\hline 74 & $\begin{array}{l}\text { South Clay Hill } \\
\text { Point (P) }\end{array}$ & $\begin{array}{l}\text { Pits, trenches, ditches, } \\
\text { and hydraulic workings }\end{array}$ & $\begin{array}{l}\text { Bench gravel. Estimated production of } \\
30,000 \mathrm{yd}^{3} \text { mined and resources of } 30,000 \\
\mathrm{yd}^{3} \text {. Gravell estimated to contain } 0.00003 \\
\text { oz gold } / \mathrm{yd}^{3} \text {. }\end{array}$ \\
\hline 75 & Unnamed Bench (P) & None & $\begin{array}{l}\text { Bench gravel, landslide, and slopewash } \\
\text { deposits. About } 3,000,000 \mathrm{yd}^{3} \text {. One } \\
\text { placer sample contained no gold but } \\
\text { another contained } 0.00041 \mathrm{oz} / \mathrm{yd}^{3} \text {. }\end{array}$ \\
\hline 76 & Fall Creek (P) & None & $\begin{array}{l}\text { Modern-day creek and small bench gravel } \\
\text { deposits. A placer sample contained } \\
0.000011 \text { oz gold } / \mathrm{yd}^{3} \text {. }\end{array}$ \\
\hline 77 & Flora Dell Creek (P) & None & $\begin{array}{l}\text { Modern-day and bench gravel from an area of } \\
\text { sedimentary rocks. A panned sample } \\
\text { contained } 0.000089 \text { oz gold/yd. }\end{array}$ \\
\hline 78 & Flea Creek (P) & None & $\begin{array}{l}\text { Modern-day and bench gravel from an area of } \\
\text { sedimentary rocks. A panned sample } \\
\text { contained } 0.00001 \text { oz gold } / \mathrm{yd}^{3} \text {. }\end{array}$ \\
\hline \multirow[t]{2}{*}{79} & Hioks Creek Bar (P) & $\begin{array}{l}\text { Trenches, pits, and } \\
\text { ditches }\end{array}$ & $\begin{array}{l}\text { Estimated } 30,000 \mathrm{yd}^{3} \text { gravel mined. } \\
\text { Estimated resources of } 800,000 \mathrm{yd}^{3} \text {. } \\
\text { Gravel estimated to contain } 0.0003 \mathrm{oz} \\
\text { gold } / \mathrm{yd}^{3} \text {. }\end{array}$ \\
\hline & Hicks Creek (P) & None & $\begin{array}{l}\text { Modern-day and bench gravel from an area of } \\
\text { edimentary rocks. A panned sample } \\
\text { contained no detectable gold. }\end{array}$ \\
\hline 81 & Slide Creek Bar (P) & W & W \\
\hline 82 & Slide Creek (P) & W & W \\
\hline 83 & Dans Creek Bar (P) & $\begin{array}{l}\text { Small trenches and } \\
\text { ditches }\end{array}$ & $\begin{array}{l}\text { Bench and modern-day gravel, affected by } \\
\text { landsliding and slopewash. Five placer } \\
\text { samples from benches at or near the mouth } \\
\text { of Dans Creek contained an average of } \\
0.0000013 \mathrm{oz} \text { gold/yd }\end{array}$ \\
\hline 84 & Dans Creek (P) & None & $\begin{array}{l}\text { Modern-day and bench gravel from an area of } \\
\text { sedimentary rocks. Some landsliding has } \\
\text { affected the area. A panned sample } \\
\text { contained } 0.000499 \text { oz gold/yd }{ }^{3} \text {. }\end{array}$ \\
\hline 85 & Watson Creek (P) & None & $\begin{array}{l}\text { Modern-day creek and small bench gravel } \\
\text { deposits. A placer sample contained } \\
0.00068 \text { oz gold/yd }\end{array}$ \\
\hline
\end{tabular}




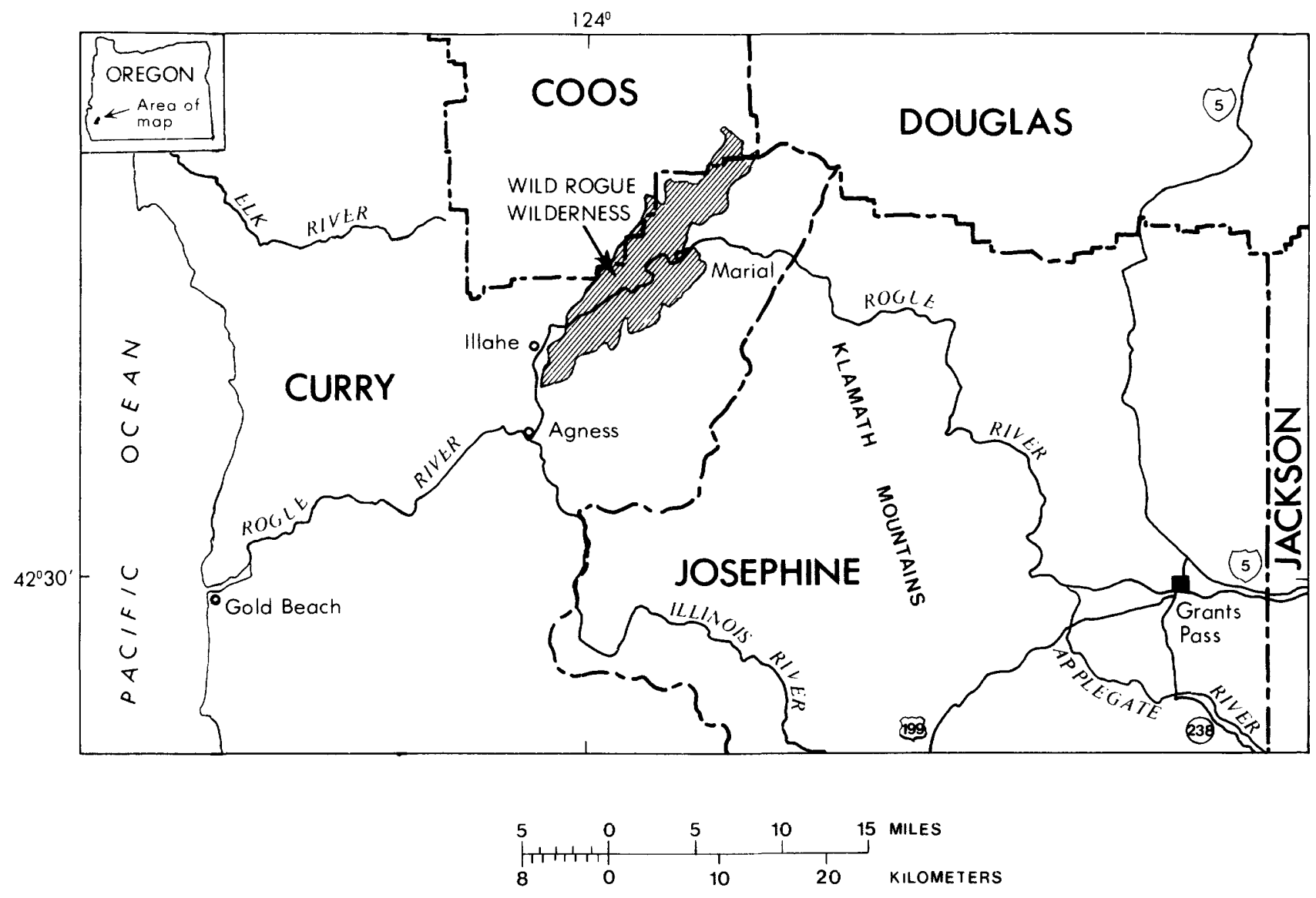

Figure 1.--Location of Wild Rogue Wilderness (NF105), southern Oregon. 


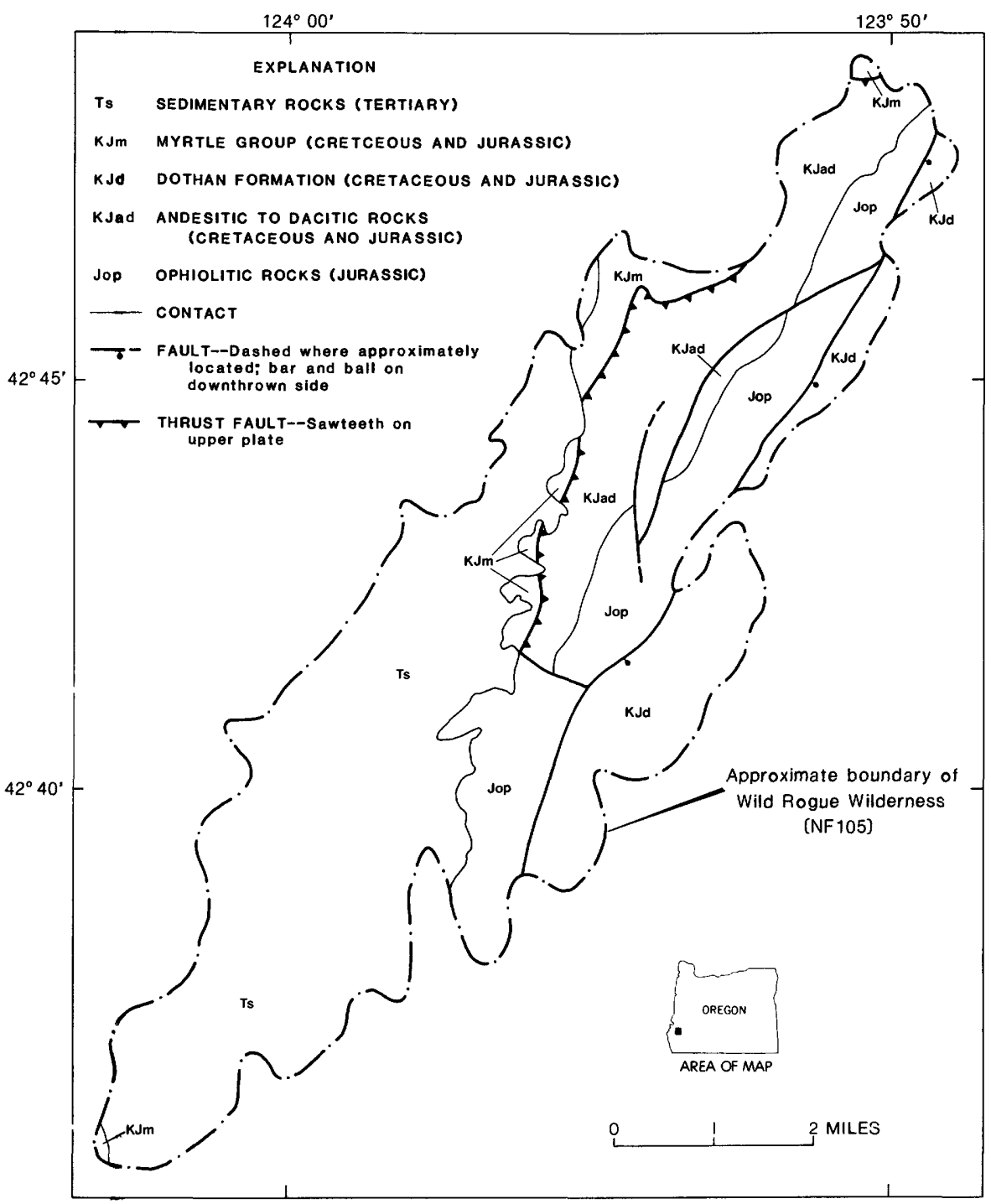

Figure 2.--Simplified geologic map for Wild Rogue Wilderness (modified from Gray and others, 1982). 


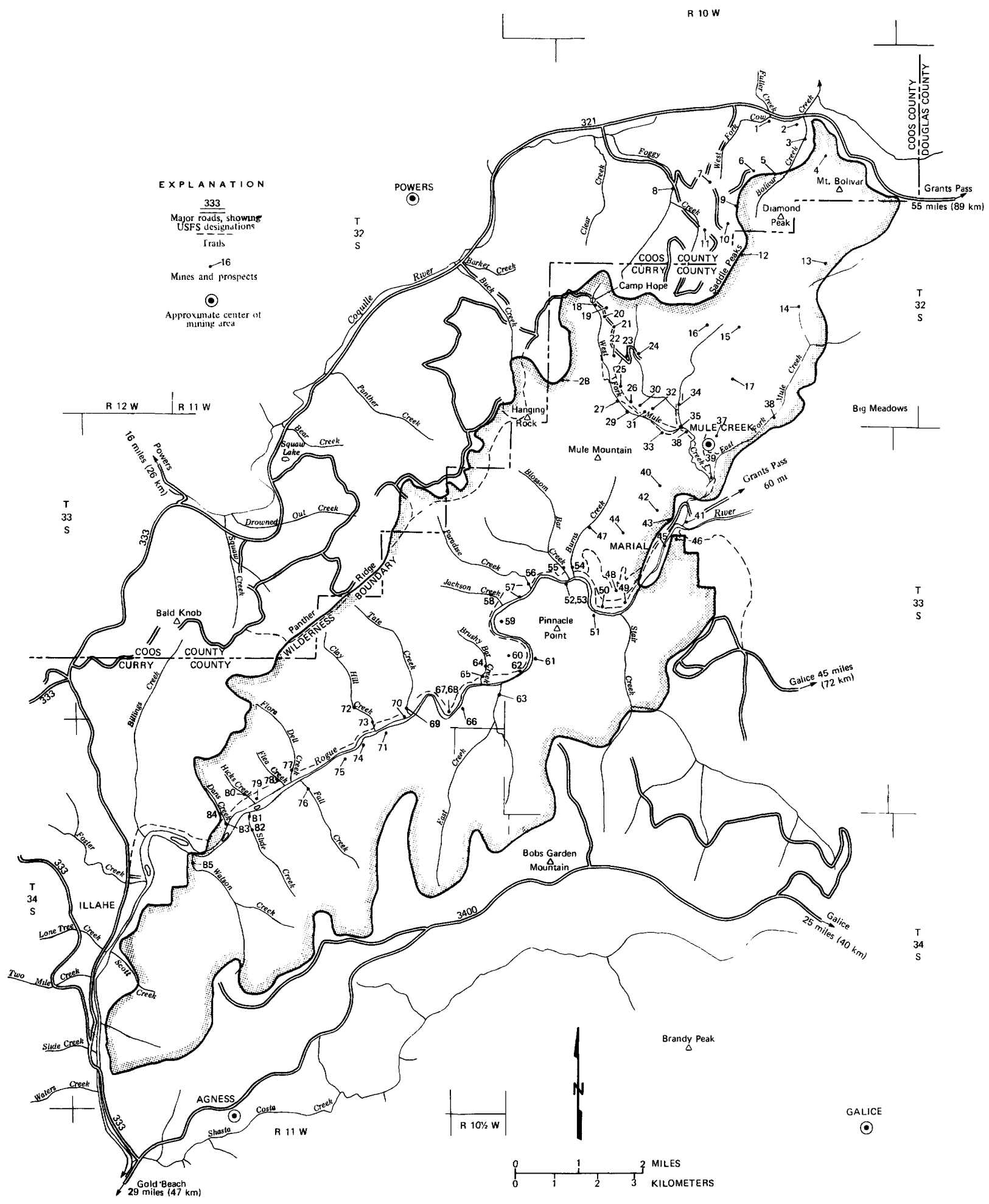

Figure 3.--Mines and prospects in and near the Wild Rogue Wilderness, Oregon. Names and descriptions are in table 2. 


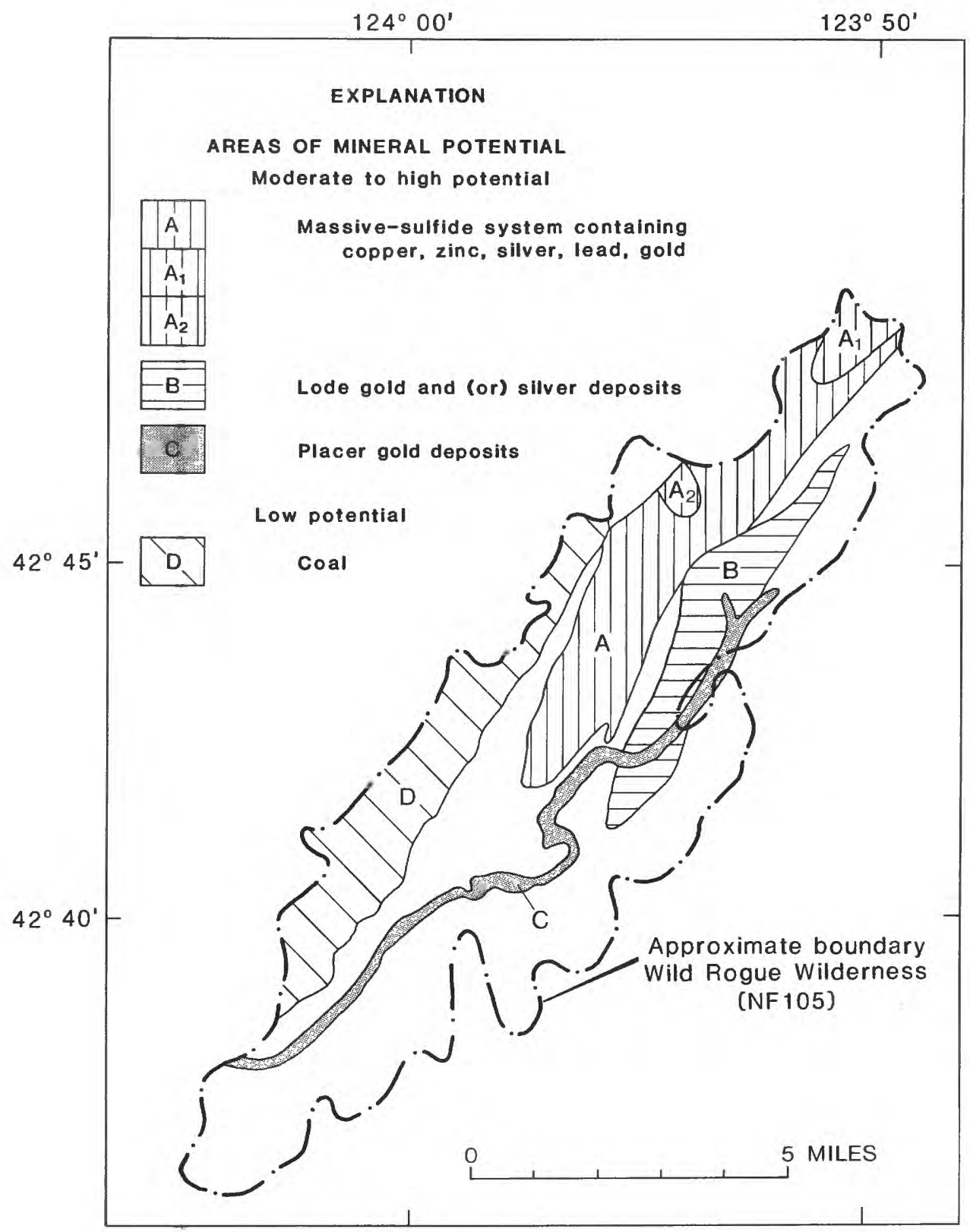

Figure 4.--Sketch map showing areas of mineral resource potential in the Wild Rogue Wilderness, Oregon. 
